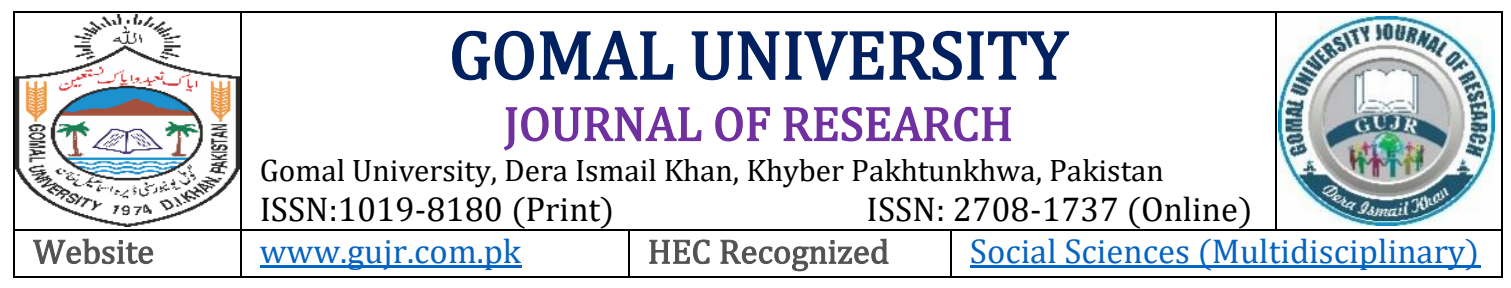

\title{
THEOCRATIC AUTOCRACY IN PAKISTAN BETWEEN 1977 TO 1988 FROM THE PERSPECTIVE OF GRAMSCI'S THEORY OF CULTURAL HEGEMONY
}

\author{
Muhammad Uzair Hashmi \\ Department of Political \& Public Administration, Middle East Technical University, TURKEY
}

\begin{tabular}{|c|c|}
\hline ARTICLE INFO & ABSTRACT \\
\hline $\begin{array}{l}\text { ny, } \\
\text { Civil } \\
\text { tured } \\
\text { toric Bloc }\end{array}$ & \multirow{2}{*}{ 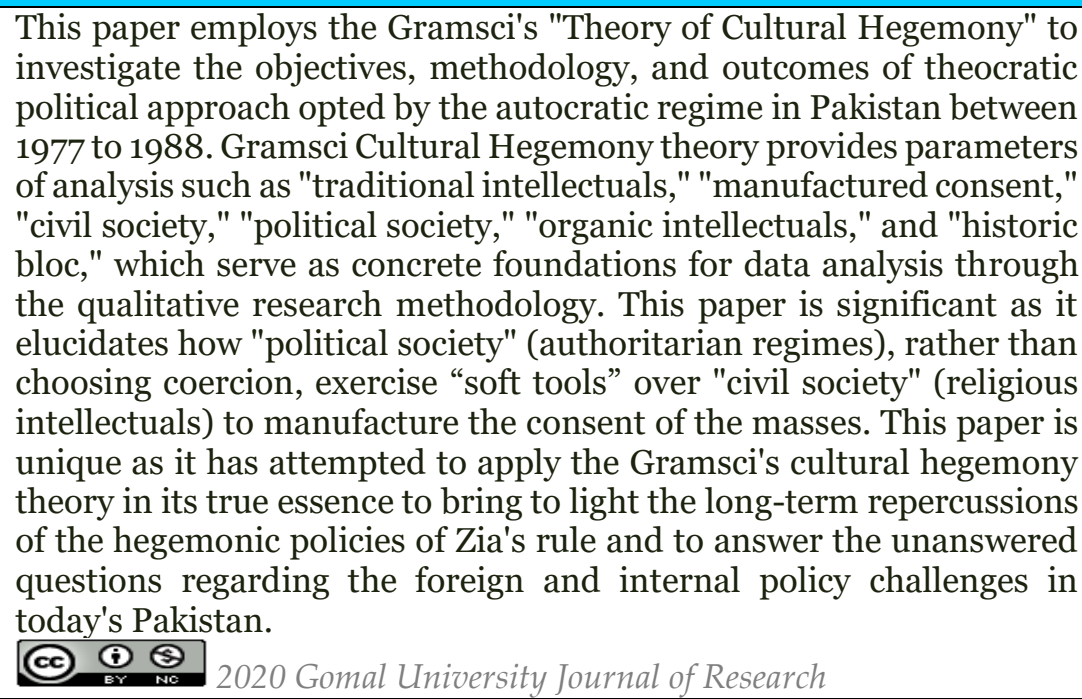 } \\
\hline $\begin{array}{l}\text { Article History: } \\
\text { Date of Submission: } \\
\text { 01-10-2020 } \\
\text { Date of Acceptance: } \\
\text { 16-03-2021 } \\
\text { Date of Publication: } \\
\text { 31-03-2021 }\end{array}$ & \\
\hline Corres & uzairhashmi2@gmail.com \\
\hline DOI & /doi.c \\
\hline
\end{tabular}

\section{INTRODUCTION}

There is considerable academic work available on autocratic rule in Pakistan. However, a significant research gap exists in Pakistan in terms of employing a specific political philosophy like Gramsci's theory of the cultural hegemony to analyze it. The current political instability, societal decline, and economic debacle in Pakistan have often been blamed as an indirect result of policies opted during the country's autocratic era between 1977 to 1988. This paper analyses the said period through the lens of "Cultural Hegemony" postulated by Gramsci and argues that the "soft ideological tools" have far more long-term effects than conventional autocratic tools such as coercion. The paper, in light of Gramsci's Hegemony theory, comments on the role of religious intellectual (civil society) during the autocratic rule between 1977 to 1988 in "manufacturing" the consent of the people of Pakistan to establish cultural hegemony. The paper also questions the motives behind using belief as a tool, whether its sole purpose was prolonging Zia ul Haq's rule or if there was an extended hidden agenda such as facilitation of Pakistan's involvement in Afghan War against Soviet Union. The discussion 
of current study assisted in exploring the "counter-hegemonic struggle," "passive revolution," and the "historic bloc" concepts in the context of Zia's era in Pakistan's politics. Furthermore, the socioeconomic and socio-political repercussions of Islamization in Pakistan are part of this research study.

Nationalism and religion are historically the most common tools to gather majoritarian support. As a result, the non-dominant groups of society get marginalized (Adeney, 2015). Majoritarianism has always been populist the politicians and dictators' favorite tool to gain populous support and legitimize their rule (Mudde, 2017). Since Pakistan came into being as a Muslim democracy, Islam has always been dearest to the masses that is why it has been used by every ruler, whether a dictator or democratic. However, General Zia-ul-Haq is considered the most successful dictator in using religion to gain public acceptance after overthrowing a democratically elected government in 1977. The most prominent feature of Zia-ul-Haq's rule was the policy of Islamization, which was applied to all walks of life. With Cold War at its peak, he took advantage of time and again aligned Pakistan with the Western bloc to fight "infidel" Soviets to protect Islam in Afghanistan. He was aware and well prepared to use religious sentiments to win people's popular support. For this drive, he activated an articulately designed propaganda machinery through agency of the country's religious political parties (Ahmed, 2012). General Zia succeeded to introduce theocratic populism in legislation which was then frequently used as a tool to coerce people during his rule between 1977 to 1988 (Kennedy, 1988).

\section{LITERATURE REVIEW}

This paper contains a two-pronged review of the existing literature on the topic under study. The first part examines Gramsci's "Theory of Cultural Hegemony" and its terminologies to analyze the "soft tools" used by autocratic regimes to ignite passive revolutions through "civil society" and role of the "organic intellectuals" in forming a "historic bloc" to counter the hegemonic measures of the ruling class. The second part revisits literature to scrutinize Pakistan's political history needed to put the theoretical parameters in perspective. It further identifies "civil society," "political society," "manufactured consent" of the masses, "historic bloc," and the "organic intellectuals" in Pakistan's case.

\section{Antonio Gramsci and Theory of Cultural Hegemony}

Antonio Gramsci was a political scientist, a politician, the founder of Italy's first communist party, and an active force against Mussolini's fascist regime. He was a Parliament member with political immunity when he was unlawfully arrested and imprisoned for eleven years. The prison years though the harshest of his life, were also most productive. He wrote most of his political theories, including the theory of "Cultural Hegemony," in captivity in what came to be known as the "Prison Notebooks," published posthumously (Adamson, 1980). This paper utilizes Gramsci's theory of the "Cultural Hegemony," which postulates that to influence the ruled class, coercion and power alone are not enough, and ideas play a pivotal role. He explains how the ruling class influences the masses' thought process by employing soft intellectual tools of ideology executed over social institutions. The noticeable feature of "cultural hegemony" is that it does not use the forceful methods to coerce people; instead, it convinces people by using the populous slogans to win over their support (Lears, 1985). Gramsci furthered the Marxist thought that "the ruling ideas of each age have ever been the ideas of its ruling class" by describing how the ruling class formulates ideas and then imposes them in a manner that unbeknownst to the ruled class, they start believing in them as their own (Bates, 1975).

Gramsci presents a scenario where "political society" in a coalition with "civil society" succeeds in influencing ruled class's thoughts to form "cultural hegemony." The "political society" encompasses 
the ruling class that has the power to exercise legal authority over people through state institutions, whereas the "civil society" consists of intellectuals having the power to influence the thoughts of the masses by using private organizations such as the churches, schools, print media, and private gatherings. Gramsci argues that when "civil society" fails to "manufacture" the ruled class's consent in a manner desired by the "political society," the "political society" always has an alternative plan, suppressing the ruled class through coercion and power alone (Weszkalnys, 2007). He further argues the case of "counter-hegemonic" forces formed through the section of society he labels the "organic intellectuals." According to him, if a society succeeds in producing "organic intellectuals," whose interests do not align with those of the "political society," only then can the fate of the proletariat be turned around. These intellectuals may create a "historic bloc," which can wage the "war of position" against the tyrannical "political society" and make it irrelevant through knowledge and awareness and formulate a new "political society" based on the "principle of equality" (Bates, 1975).

\section{Case of Pakistan}

Pakistan is an ideological state secured in the name of Islam. The "Two Nation Theory," the basic principle behind Pakistan's creation in 1947, stated Islam as the primary identifier and unifier of the Indian subcontinent's Muslims. Pakistan guaranteed to protect the rights of all the citizens regardless of their ethnicity and religious beliefs, Mr. Muhammad Ali Jinnah (the founder of the Pakistan) in his speech on August 11, 1947, expressed his intention for Pakistan to be a state where though the Muslims will be in the majority, but there would be religious freedom for minorities and equality of all. Nevertheless, as early as 1956, Pakistan's first constitution declared the country an "Islamic Republic" due to the pressure exerted by Jammat-i-Islami and the other prominent clerics. However, constitutionalism could not sustain in Pakistan due to severe political instability, which eventually provided an excuse to the President of Pakistan, Mr. Sikandar Mirza, to impose martial law in 1958. General Ayub Khan was pronounced the chief martial law administrator (Hussain \& Kokab, 2013), but within 20 days of the taking charge, Ayub Khan sacked and exiled Mr. Sikandar Mirza and assumed power as head of the state, and initiated the first dictatorship era in Pakistan (Editorial, 2019). The prolonged imposition of martial law between 1958 to 1969 changed the country's priorities in terms of foreign policy when Ayub Khan started establishing strong ties with Western Bloc during the Cold War to protect Pakistan from 'infidel' communist expansion (Lerski, 1974).

The utilization of religion as a "policy tool" was not limited to external affairs but was also used to suppress opposing voices inside country. During the presidential elections of 1965, he used Muslim clerics to issue a fatwa against candidature of Ms. Fatima Jinnah based on Islamic interpretation prohibiting rule of a woman (Ansari, 2011). After end of Ayub's martial law, democratically elected government of Mr. Zulfiqar Ali Bhutto until its end, frequently used Islam as a policy tool (Richter, 1979). The 1970 s were crucial in terms of political upheavals both in Middle East and South Asia. The whole region was going through significant paradigm shift from secularism to theocracy, which greatly affected Pakistani politics. After suspending Pakistan's constitution in 1977 and imposing martial law, General Zia had two crucial issues that needed resolution. The first one was to win the people's support and, the second was to keep the Western bloc happy by joining the war against the Soviets in Afghanistan, and motive was to minimize internal and external resistance. Zia's regime used "religion" as "soft tool" to garner support of the people and establish his hegemony in coalition with the clergy of Pakistan that could help modify populace's opinions. The alliance between the military government and Jamaat-i-Islami, to religious groups, proved very useful in manufacturing the people's opinion that Islam was under threat and General Zia was only person who could protect it.

Gomal University Journal of Research, Volume 37, Issue 1, MARCH, 2021 
The religious scholars further advanced the government's propaganda to support the American-led war against Soviets in Afghanistan. The clergy systematically preached to the people that the Soviet aggression in Afghanistan was an attack on Islam and it will extend to Pakistan also. Hence it was Pakistan's responsibility as Islamic Republic to wage Jihad against the Soviet Union, and the people must join in fighting the holy war against the "Godless" communists (Kennedy, 1990). During the Cold War, Pakistan was part of Western Bloc from the very initial years after its inception. However, during the military regime of Ayub Khan, Pakistan and USA developed very strong ties that did not last long after end of martial law. The incoming democratically elected government of Mr. Bhutto had a very different foreign policy agenda and while using Islam, it took a populist approach to create an Islamic bloc. However, it did not last long, in 1977 after overthrowing Bhutto, General Zia tried to change foreign policy's trajectory and repaired Pakistan-US relations by joining the Afghan War in exchange for political and financial support from USA. Pakistan's geographical positioning was suitable for serving American agenda and fighting its war against Soviets in Afghanistan. Since this was a proxy war, it required external human resources (mujahideen) from general masses, as result, thousands of young people were indoctrinated to fight against Soviets in Afghanistan (Shah, 2012).

\section{RESEARCH METHODOLOGY}

The study employs a qualitative research methodology by taking the Gramsci's Cultural Hegemony theory as the basic yardstick for analysis as it provides substantial ground for deductive reasoning. Since this is a study dealing with the country's political history, the primary sources of the data collection are the books, journal articles, and newspapers. The aim of conducting this analysis is to ascertain how far the ideological hegemonic "soft tools" can help in prolong the autocratic rule compared to conventional coercion; for this purpose, General Zia's military rule has been taken as a case study. This paper will contribute to the body of the knowledge by testing the relevance of the Gramsci's theory of cultural hegemony as applied to the era under study. The paper will further contribute by identifying "civil society," "political society," "organic intellectuals," "historic bloc," and the "manufactured opinion" of the masses in Pakistan's political landscape. The paper further provides a foundation for a holistic analysis of Pakistan's political history in the context of Gramsci's thought.

\section{DATA ANALYSIS}

Although Gramsci's theory of cultural hegemony can be applied to Pakistan whole history seeing the use of religion as a policy tool, however, this paper limits the analysis to ascertain its relevance within context of military regime of Zia-ul-Haq. For this purpose, some of the main concepts are as follows.

\section{Religious Intellectuals as Civil Society}

Before the military coup of General Zia in 1977, Pakistan People's Party (PPP) with its slogan "Islam, Democracy, and Socialism" was in power under the leadership of Zulfiqar Ali Bhutto. Bhutto's inclination towards socialism was a bone of contention between the ruling party and the religious intellectuals of the time. Socialism was considered a "Godless" and an "Anti-religion" philosophy and a threat to Islam by the religious elites. To counter the ruling class, religious political parties formed the Pakistan National Alliance under the aegis of the establishment and started an agitation movement against the PPP. Religion plays a crucial role in the lives of the masses in Pakistan, a fact well known to the agitators; thereby, this movement quickly roused the sentiments of the masses as it was in the name of "Islam." This movement gained mass support resulting in political chaos, inevitably causing the discontinuation of democracy in Pakistan and martial law being imposed by General Zia-ul-Haq. In this scenario, the religious elites acted as "civil society," which helped justify the military coup (Chawla, Qutab, Rahman, \& Riaz, 1993). During Zia's era, the religious wing 
acting as a "civil society" worked in tandem with the military regime to influence the opinions and gain the society's consent through specially designed course curriculums, madrassas (religious schools), mosques, and state-controlled media. This new stream of education and dispensation of information was geared towards preaching a version of "Islam" that suited agendas of General Zia's regime.

The need for "Jihad" against the "Atheist" Soviets was propagated among the masses giving rise to a section of society that acted as an extension of Pakistan's religious "civil society." These unwitting sympathizers of one of Zia's prime agendas supported cause of "Jihad" monetarily and also became the human resource in the American proxy war being fought in Afghanistan (Shan, Waris, \& Basit, 2016). During Zia's regime, "Islamic laws" borrowed from Saudi Arabia were introduced in Pakistan with the support of select religious intellectuals. Although most of Pakistani population is Muslim, several sectarian divisions exist in the country, mainly Sunni and Shia. Zia's legal modifications had a distinctive Sunni bent, which was not welcomed by the Shia population in Pakistan. It gave rise to a Shia-Sunni conflict, which later turned into militant and armed conflicts with the growth of the organizations like Sipah-e-Sahaba in Pakistan (Hussain, 2010). Having the military and the law enforcement system at his disposal, General Zia-ul-Haq had means of coercion over the ruled class. However, he knew that to prolong his rule, he needed religious intelligentsia on his side. He used religious elites as his soft power to manipulate Islam's ideas to shape the people's consent. This religious intelligentsia succeeded in getting popular support for Zia's agendas. It also led Pakistan into a new era of theocratic jurisprudence with the new stream of banking, administration, election system, and social practices. The aim was to replace Anglo-Saxon legal regime (Sheikh \& Ahmed, 2020).

\section{Political Society}

To an extent, the military regime merged the clergy into a "political society" by giving them powers to guide the so-called legislature in lawmaking in the light of religion. With the unprecedented legal and monetary power through donations both from United States and Saudi Arabia at their disposal, the clergy designed a new educational policy. Under this policy, a new schooling system in the form of madrassas (religious schools) was introduced, and the main topics of education were "Jihad" and anti-Communist literature. The political power given to the clergy enabled it to indoctrinate youth to fight against the Soviet Union in Afghanistan (Ashraf, 2009). The religious intelligentsia played the role of "civil society" and integral part of "political society" with powers to enforce the religious philosophy over the masses. Those who dared to question government and clergy were considered a threat to Islam and harshly punished to make an example. There was no room for the expression of criticism, the sole source of information for people was state media, and all kinds of private media were victim of harsh censorship. There was a range of laws based on misinterpretation of religion and nationalism, aimed to silence voices of political workers, journalists and general public (Lau, 2007).

\section{Passive Revolution}

According to Gramsci, the authoritarian state sometimes allows masses to practice limited rights in the form of protest, freedom of speech, and forming political parties; Gramsci called this practice "passive revolution." A passive revolution can hardly bring any change in existing power structure, and it solely gives a false sense of freedom to the people (Thomas, 2013). After Zia imposed martial law in 1977, he promised to conduct elections within 90 days and bring democracy back on its track. This promise was not to be honored for the next eight years, and people were ruled first through coercion and then through "cultural hegemony." When these options did not prove the fruitful, Zia decided to bring a sham democracy to the country. In 1985 he arranged the non-party elections, and Muhammad Khan Junejo was nominated as the sole candidate by the military dictator for the prime 
minister's position (Tahir, 2009). These elections were thus held after Zia got his presidential term extended through a controversial referendum in which people were asked whether they wanted to support Islamization, which, if answered in the affirmative, meant support for General Zia as the President for the next five years. The newly elected assembly passed the constitutional amendments that empowered the president to dissolve the national and provincial assemblies at any time (Aziz, 2015).

This democratization process during the military regime is a prime example of what Gramsci calls a "passive revolution" as not only were the people made to feel that they had a voice through the farce of referendum, but also Prime Minister was installed to appease the sentiments of the people. At the same time, real power still lay with the military dictator. Another incident is the controversial trial of the overthrown Prime Minister of Pakistan Zulfiqar Ali Bhutto over a murder in which he was implicated and consequently executed (Richter, 1979). Bhutto was the head of the Pakistan People's Party (PPP), the most successful political party in Pakistan, with roots in the province of Sindh. To diminish the influence and the popularity of PPP in Sindh, Zia and his regime supported another political party, the Muhajir Qoumi Movement (MQM now Muttahida Qaumi Movement). It was a party with the fragile mandate as it claimed to only stand for the rights of the muhajirs (immigrants) who migrated to Pakistan after the partition in 1947 and is believed to be involved in armed violence on ethnic basis. It is another prime example of a "passive revolution" during Zia's era, where the state nurtured a political party to undermine political opponents' powers (Hussain, 2010).

\section{Counter Hegemony and Historic Bloc}

General Zia tried to design a hybrid system where sham democracy would work alongside martial law. After 1985 election was held on a non-party basis, since all political parties were banned during Zia's regime, a weak federal government was installed while in all four provinces, state-backed chief ministers were installed. Unexpectedly Prime Minister Junejo emerged as a powerful politician, challenging the presidential powers, with the majority of the political elites supporting him. During this unanticipated power struggle, to weaken Junejo's position, General Zia attempted to create a new political force within the legislature, which would superficially support the civilian leadership but would be loyal to General Zia. In this connection, the aim was to try to defunct Junejo from the prime minister's position through a "vote of no confidence." It did not come to fruition, and General Zia eventually had to openly crush the "counter-hegemonic" forces by using his constitutional authority and powers and dissolving both national and provincial assemblies in the country (Tahir, 2009).

The discussion calls for why the "counter-hegemonic" forces failed to form a "historic bloc" during Zia's regime. The "counter-hegemonic" struggle that started to take form and resist the dictatorship was crushed due to the constitutional endorsement of the military rule, which thus conferred on the president's unparalleled powers. Due to a lack of "organic intellectuals," these forces could not gain support from the ruled class, which was less educated and unaware of their basic rights. As this remained an elitist power struggle, the synergy imperative in formation of Gramsci's "historic bloc" never took shape. Also, another vital factor missing from the equation was education and awareness of ruled class. Gramsci, in his Prison Notes VI and XII, states education and awareness as a prerequisite for the ruled class to join hands with the "organic intellectuals" to overthrow the authoritarian regime. He defined the "organic intellectuals" as educated people who are aware of their rights and, in turn, educate the masses to unite against the tyranny of an autocratic capitalist superstructure. 


\section{DISCUSSION}

The article argues that the "manufactured consent" generated by the "civil society" (religious bloc) in alliance with the military regime of General Zia resulted in adverse long-term effects. It helped establish the theocratic hegemony empowering religious elite in Pakistan, resulting in a confused society still struggling to recover. The alliance between military regime and religious intelligentsia treated any opposition to their hegemony as being contemptuous and harshly punishable. Thus, a counter-hegemonic struggle could hardly take off. The repercussions of the Afghan proxy war that Pakistan was pulled into in name of religion in 70 s can be felt today in Pakistan and internationally. Pakistan, along with its ally the United States, sponsored "Mujahideen" (Freedom Fighters), who later shaped into the Al-Qaida, now one of the largest terrorist outfits. In this connection, these yesteryear heroes proved to be a wrong strategic investment for Pakistan, as it embroiled Pakistan in a civil war, which claimed thousands of lives, both the civilian and military personnel (Tariq, 2011).

On the international front, these fighters attacked their other sponsor USA on its home front on the September 11, 2001, changing world's geopolitics. Today Pakistan is weak, insecure, war-stricken, politically and economically unstable, hard hit by terrorism, dealing with the Afghan refugee crisis, and intolerant due to flawed interpretation of theocratic ideology by Zia's "political society" with help of religious intelligentsia - "civil society" to create its' "cultural hegemony." The unprecedented powers attained by the religious elite have posed a constant threat of domestic instability owing to the difference of opinion between different Islamic sects. Furthermore, despite being dangerous for religious minorities, legislation set in place during Zia's regime has become impossible to amend or be reversed due to the clergy's pressure. There are numerous examples of the clergy instigating people to take the law into their hands, resulting in the harm caused to the society's vulnerable groups.

\section{CONCLUSION}

Although Gramsci came up with theory of "cultural hegemony" a century ago when Italy was going through extreme fascism, his thoughts are not time-bound and are equally relevant today. Every authoritarian regime intends to prolong its rule and, knowing that the methods based on coercion may not last long, turns to "soft tools." Thereby people's opinion is "manufactured" so that it gets aligned with the state's ideology. An authoritarian regime - "political society" does not have to work hard to find religious intellectuals - civil society to manufacture consent of masses. It only depends on which kind of a regime is in power and what kind of a framed consent it needs. The nature of framed consent can vary from society to society; all that is required is knowledge of what triggers the masses' emotional response. The societies where a single ethnicity is in majority make it easier to shape people's consent through nationalistic or linguistic policy tools. Consequently, this paper has attempted to fill the research gaps in the political history of Pakistan, mainly on two accounts. The first one deals with examination of autocratic regime of General Zia through Gramsci's cultural hegemonic perspective to understand the nature of "soft tools" employed to prolong the dictatorial rule. In this connection, the second lacuna this paper fills are by elucidating the repercussions of various policies implemented during the era under study, the echoes of which reverberate even today.

In Pakistan's case, the paper has ascertained that history provides enough evidence that the people divided into different ethnic identities get united only in the name of Islam since the conception of Pakistan is based on theocratic ideology. Thus, it made it easier for General Zia's military regime to play on the emotions of Pakistani populace using "Islam" as a "policy tool." The theocratic cultural hegemonic power became unchallengeable, rendering the "counter-hegemonic" forces powerless. The state used organized propaganda machinery through the specially tailored educational syllabus 
in schools and state media to proliferate theocratic ideology based on exact religious interpretations. Through the indoctrination carried out by the religious elite in Pakistan's case, the "civil society," "Islam," became synonymous with Pakistan's identity. Although the state preferred "manufactured opinion" as a tool to win the masses; however, it did not hesitate to use oppressive methods to curb resistance. The "manufactured opinion" made harsh suppression of "counter-hegemonic" forces effort-free for the autocratic regime by labeling the political opponents corrupt and an enemy of the state and, by extension, "Islam." The voices of "organic intellectuals" were silenced through harsh punishments, and as the masses were uneducated and unaware of their rights, it became practically impossible to form "historic blocs," which could stand against the oppressive regime. Based on the arguments presented above, the paper posits that although the autocratic regimes may have enough powers to coerce the masses, they still prefer to choose hegemonic tools. They understand that "soft tools" are far more effective means of the establishing hegemony in comparison to conventional coercion. Furthermore, the hegemony created through "soft tools" is by far more long-lasting; the current socio-economic situation of Pakistan may be referred to as the evidence in support of this argument.

\section{REFERENCES}

Adamson, W. L. (1980). Hegemony and Revolution: A Study of Antonio Gramsci's Political and Cultural Theory. University of California Press.

Adeney, K. (2015). A Move to Majoritarian Nationalism? Challenges of Representation in South Asia. Representation. https://doi.org/10.1080/o0344893.2015.1026213.

Ahmed, Z. S. (2012). Political Islam, the Jamaat-e-Islami, and Pakistan's role in the Afghan-Soviet War, 1979-1988. In Religion and the Cold War: A Global Perspective.

Ansari, S. (2011). Forced modernization and public policy: A case study of Ayub Khan era (195869). Journal of Political Studies, 18(1), 45.

Ashraf, N. (2009). The Islamization of Pakistan, 1979-2009. The Middle East Institute Washington, DC, 9-11. Retrieved from https://www.mei.edu/sites/default/files/publications/2009.07. Islamization of Pakistan.pdf.

Aziz, S. (2015). A leaf from history: Zia's referendum. The Daily Dawn. Retrieved from https://www.dawn.com/news/1197376.

Bates, T. R. (1975). Gramsci and the Theory of Hegemony. Journal of the History of Ideas. https://doi.org/10.2307/2708933.

Editorial. (2019, November 15). Iskander Mirza. The Daily Dawn. Retrieved from https://www.dawn.com/news/1516819.

Hussain, M., \& Kokab, R. U. (2013). Institutional influence in Pakistan: Bureaucracy, cabinet, and parliament. Asian Social Science, 9(7), 173-178. https://doi.org/10.5539/ass.v9n7p173.

Hussain, S. E. (2010). Terrorism in Pakistan: Incident patterns, terrorists' characteristics, and the impact of terrorist arrests on terrorism. University of Pennsylvania,

Chawla, M., Qutab, H., Rahman, N., \& Riaz, A. (1993). Islamization in Pakistan: An overview. JRSP, 265-281. Retrieved from http://pu.edu.pk/images/journal/history/PDF-FILES/16-\%oA PC M Iqbl_Chawla_52-1-15.pdf.

Shah, J. (2012). Zia-Ul-Haque and the Proliferation of Religion in Pakistan. International Journal of Bussiness and Social Science.

Kennedy, C. H. (1988). Islamization In Pakistan: Implementation of the Hudood Ordinances. Asian Survey. https://doi.org/10.2307/2644489.

Kennedy, C. H. (1990). Islamization and Legal Reform in Pakistan, 1979-1989. Pacific Affairs. https://doi.org/10.2307/2759814.

Lau, M. (2007). Twenty-Five Years of Hudood Ordinances - A Review. Washington and Lee Law Review, 64(4). Retrieved from https://scholarlycommons.law.wlu.edu/wlulr/vol64/iss4/2/.

Lears, T. J. J. (1985). The Concept of Cultural Hegemony: Problems and Possibilities. The American 
Historical Review. https://doi.org/10.2307/1860957.

Lerski, G. J. (1974). The foreign policy of ayub khan. Asian Affairs. https://doi.org/10.1080/ 00927678.1974.10587719.

Mudde, C. (2017). Populism: A Very Short Introduction. Populism: A Very Short Introduction. https://doi.org/10.1093/actrade/9780190234874.001.0001.

Richter, W. L. (1979). The Political Dynamics of Islamic Resurgence in Pakistan. Asian Survey, 19(6). Retrieved from https://www.jstor.org/stable/2643894?seq=1\#metadata_info_tab_ contents.

Shan, A., Waris, M., \& Basit, A. (2016). Islamization in Pakistan: A Critical Analysis of Zias Regime. Global Regional Review, I(I), 260-270. https://doi.org/10.31703/grr.2016(i-i).20.

Sheikh, M. Z. H., \& Ahmed, Z. S. (2020). Military, Authoritarianism and Islam: A Comparative Analysis of Bangladesh and Pakistan. Politics and Religion. https://doi.org/10.1017/ S1755048319000440

Tahir, K. (2009). Politics of Elections and Autocracy in Pakistan: Apprising the Electoral Process during Zia ul Haq's Regime. Journal of Political Studies, 15(Journal Article), 25. Retrieved from http://pu.edu.pk/images/journal/pols/Currentissue-pdf/Politics of election. pdf.

Tariq, M. M. (2011). The Rise and Impact of Islamic Fundamentalism in Pakistan After the Soviet Invasion in Afghanistan with Special Reference to Kpk and Balochistan. Bi-Annual Research Journal "Balochistan Review, XXIV (1).

Thomas, P. D. (2013). Hegemony, passive revolution and the modern Prince. Thesis Eleven. https://doi.org/10.1177/0725513613493991.

Weszkalnys, G. (2007). The anthropology of the state: a reader? Edited by Aradhana Sharma \& Akhil Gupta. Journal of the Royal Anthropological Institute. https://doi.org/10.1111/j.14679655.2007.00439_25.x. 